\title{
An overview of illegal parrot trade in Maluku and North Maluku Provinces
}

\author{
Ayu Diyah Setiyani ${ }^{1, *}$ and Mukhtar Amin Ahmadi ${ }^{2}$ \\ 1 Nature Resources Conservation Agency of Maluku (BKSDA Maluku), Jl. Kebun Cengkeh, Ambon 97128, \\ Maluku-Indonesia; aminahmadi87@yahoo.com \\ 2 Nature Resources Conservation Agency of Maluku (BKSDA Maluku), Jl. Kebun Cengkeh, Ambon 97128, \\ Maluku-Indonesia; ayu.diyah.s@gmail.com \\ *Correspondence author: ayu.diyah.s@gmail.com; Tel.: +62-821-9773-3113
}

\begin{abstract}
Maluku is widely considered as a global avifauna hotspot. However, illegal parrot trades threaten numerous species to extinction. To date, there is no study on the extent of illegal trade in Maluku, which as a result, hampers efforts at targeting conservation initiatives. The aims of this study are to identify the pattern of illegal parrot trade, to identify factors that contribute to illegal parrot trade, and to identify actors involved in illegal parrot trade in Maluku and North Maluku Provinces. The study found that the number of wildlife rescued in 2018 was 1,402 individuals. Surprisingly, 84\% (1,177 individuals) of the rescued wildlife were birds and approximately $96 \%$ (1,135 individuals) of the birds were parrots. Furthermore, the most commonly rescued parrots (90\%) were from illegal trade seizures, and the remainder were handed over voluntarily by local communities. These trends indicate that the traffic of illegal parrot trade is extremely high. Meanwhile, the small number of handovers for birds indicates that there is an insufficient understanding and awareness among locals about wildlife laws and ecological values. The study identified three factors contributing to illegal parrot trade, which are the high potential for obtaining parrots with exotic appearances; the economic value of wild-caught parrots; and overall accessibility. The characteristics of the trade involved actors that can be defined as subsistence and opportunist harvesters, that work with several intermediaries, and consumers demand for pets. To overcome these challenges, there are two strategies which are proposed based on this research: (1) expand the upstream strategy focusing on protecting parrots in their habitats and empowering local communities to be involved in conservation; and (2) engage more on downstream strategies of emphasizing law enforcement and raising awareness.
\end{abstract}

Keywords: illegal wildlife trade; parrots; Maluku; conservation challenges and strategies

\section{Introduction}

Globally, wildlife trade involving numerous species is a serious issue in biodiversity conservation (Shepherd, 2006; Nijman, 2010; Wilson-Wilde, 2010; and Harris, et al., 2015; May, 2017). On the one hand, wildlife trade contributes economic advantages that benefit individuals, groups, and states (Nijman, 2010). On the other hand, unsustainable wildlife trade without adequate regulatory processes expose several species to undue risks for their survival (Shepherd, 2006) at times affecting species that can throw entire ecosystems out of balance (May, 2017). Harris et al. (2015) explain how wildlife trade creates impacts that can lead to habitat loss and species extinction. Trade that targets various species of birds, mammals, fish, reptiles, to insects, are done for their exotic qualities, and are often the case for rare and endangered species that some individuals wish to collect as pets (Wilson-Wilde, 2010).

Bird species in particular, are especially at risk as the techniques used to catch wild-caught birds can disturb habitats, replaced by invasive species, and threaten bird populations to extinction (BirdLife-International, 2008). The most popular bird in commerce are parrots (including macaws, cockatoos, and lorries), followed by flaminggos, eagles, toucans, and a number of songbirds (Gilardi, 2006). Among parrot cases, Lezema et al. (in Gilardi, 2006) concludes that parrot populations in their natural habitats suffered $80 \%$ decline in populations over a decade due to hunting and trapping. A similar study in Brazil by Alves, Lima, \& Araujo (2013) shows that the extinction of Spix's Macaws in the wild was caused by capture for trading. 


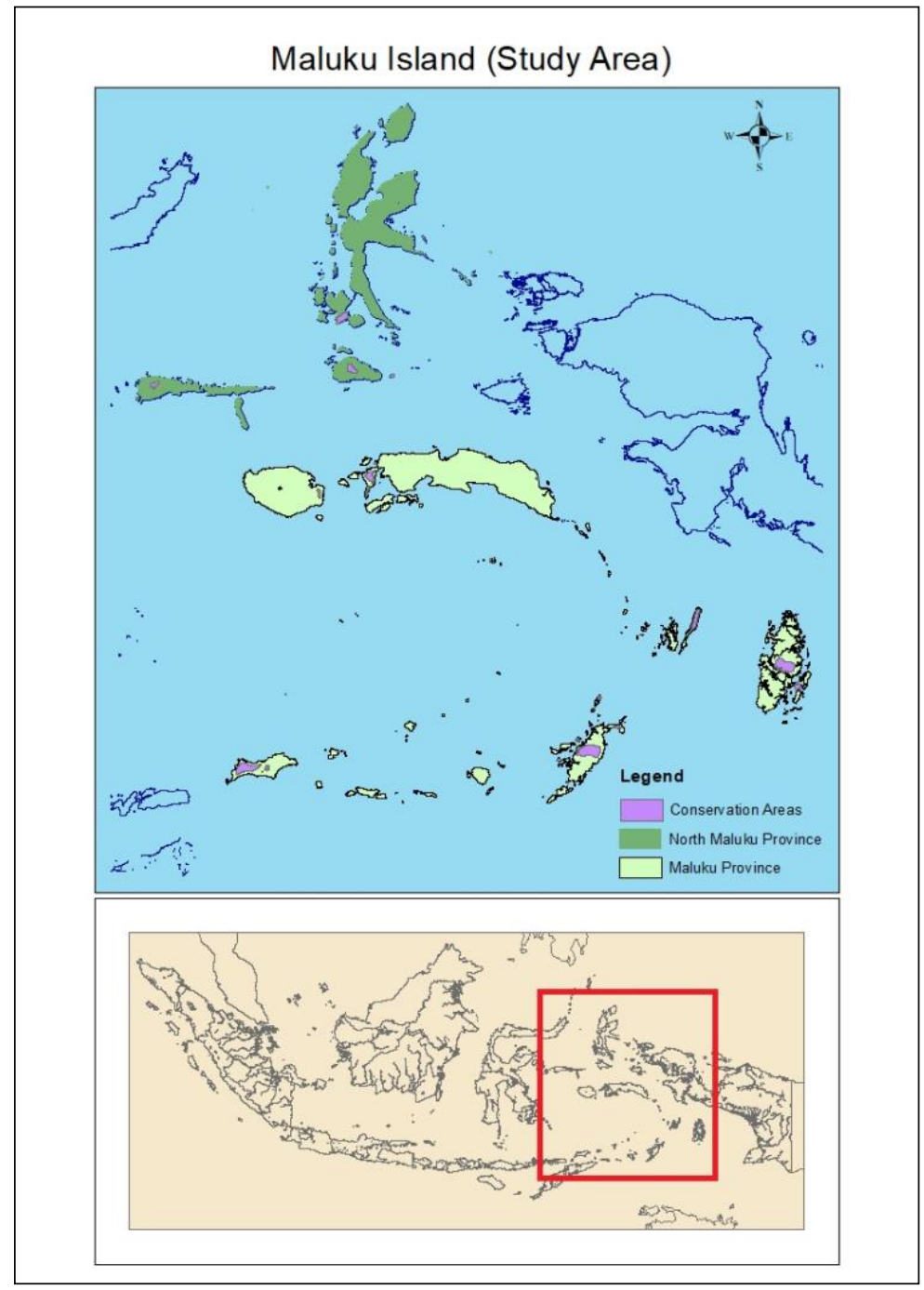

Figure 1. Study area: Maluku Islands (North Maluku and Maluku)

Admittedly, there are plenty of research addressing illegal parrot trade, including illegal trade on Neotropical parrots (e.g. Weston \& Memon 2009; Bravo \& Porzecanski 2014) and Afrotropical parrots (e.g. Martin 2018; Hart et al. 2016; and Budiani \& Raharningrum 2018). Further, Pires (2012) has also published a review on global illegal parrot trade. Nevertheless, publications on the extent of parrot trade in the Maluku Islands remains an empirical blindspot as studies are lacking in number and rigor. We identified merely three studies focussed on North Maluku parrots (Cottee-Jones et al. 2014; Cottee-Jones \& Mittermeier 2015; and Tamalene, Hasan, \& Kartika 2019). The lack of understanding about this issue for the region can have negative repercussions, especially on the overall understanding of the depth of trade networks and the potential for overlooking opportunities at conservation efforts. Therefore, this paper aims to identify the patterns of illegal parrot trade, to identify the contributing factors of illegal parrot trade, and to identify actors involved in illegal parrot trades in Maluku and North Maluku Provinces. Furthermore, this study also attempts to provide an effective strategy for tackling illegal parrot trade in the Malukus. 


\section{Materials and Methods}

\subsection{Study Area}

The study is focused on all illegal parrot trade committed across the Maluku Islands, which includes the administrative borders around Maluku and North Maluku Provinces (see Figure 1). The Maluku Islands contain the highest number of islands in Indonesia, as almost $10 \%$ of all Indonesian islands are located there. There are approximately 1,300 islands in Maluku and North Maluku Provinces. The Maluku Islands are part of the Wallacean Region, a global biodiversity hotspot (Myers et al., 2000), including for avifauna (Coates \& Bishop, 1997).

\subsection{Data collection}

The data on the number of rescued parrots and their origins were collected from illegal wildlife trade reports gathered in 2018 by the Maluku Natural Resource Conservation Agency or known as BKSDA Maluku ${ }^{1}$ (Balai Konservasi Sumber Daya Alam Maluku). The report included a compilation of data from confiscation, rescue, and patrols in seaports, airports, and villages surrounding the forest conducted by the Wildlife Rescue Unit (WRU) of BKSDA Maluku. In addition, the illegal parrot trade data were also collected from voluntarily handovers from locals to BKSDA Maluku for rehabilitation proccess and release into the wild. The redlist of IUCN was used to categorize the conservation status and to determine population trends of each rescued parrot. The study also referred to Indonesian Law (Ministry of Environment and Forestry Regulation Number P.106/MenLHK/Setjen/Kum.1/12/2018) to classify protection status of each species.

The economic value of the illegal parrot trade was calculated by multiplying the number of rescued parrots from illegal trade and the average market price of each species in three different bird markets (Jakarta, Solo, and Surabaya). These three bird markets were chosen because most of the parrots ended in these three largest bird markets in Java.

The route of illegal parrot trade was created using assembled data from interviews with poachers, bird-owners, and intermediaries ("middlemen") who transported the birds and who collected the birds from poachers. All of the interviews were conducted by the WRU. Thereafter, the number of ports and airports were compiled from of the Ministry of Transportation.

The actor typologies were arranged based on interviews with actors involved in parrot trade. The actors were characterized using a tool and terminology developed by Pheleps, Biggs, \& Webb (2016). Pheleps, Biggs, \& Webb (2016) catagorized wildlife actors into harvesters, intermediaries, and consumers; depending on their role together with their preference, motivation, and scales in market chains. The wildlife harvesters are persons or groups of persons who are directly accessing wildlife, while the intermediaries or middlemen are persons or groups of persons who supply the wildlife and associated products to the consumers, which include vendors, pet shops/sellers, logisticians, smugglers, or even colluders (Pheleps, Biggs, \& Webb, 2016). The same study also defined the consumers as wildlife end users that can be grouped based on their purposes, such as for pets, medicinal, ornamentals, or food.

Finally, all collected data were discussed among key research and policy actors in order to define the contributing factors to illegal parrot trade. The discussion included participants from BKSDA Maluku, Burung Indonesia (a non-government organization that works in wild bird conservation), WRU, and academics.

\footnotetext{
${ }^{1}$ BKSDA Maluku is a technical office of the Ministry of Environment and Forestry (MoEF) that also have working jurisdiction in Maluku and North Maluku Provinces. The responsibilities of BKSDA are to manage conservation areas designated as natural reserves, wildlife reserves and recreational parks. Their mandate includes the responsibility for regulating wildlife trade at the provincial level (MoEF Regulation Number P.08/Menlhk/Setjen/OTL.0/1/2
} 


\section{Results and Discussion}

\subsection{Patterns of Illegal Parrot Trade in the Maluku Islands}

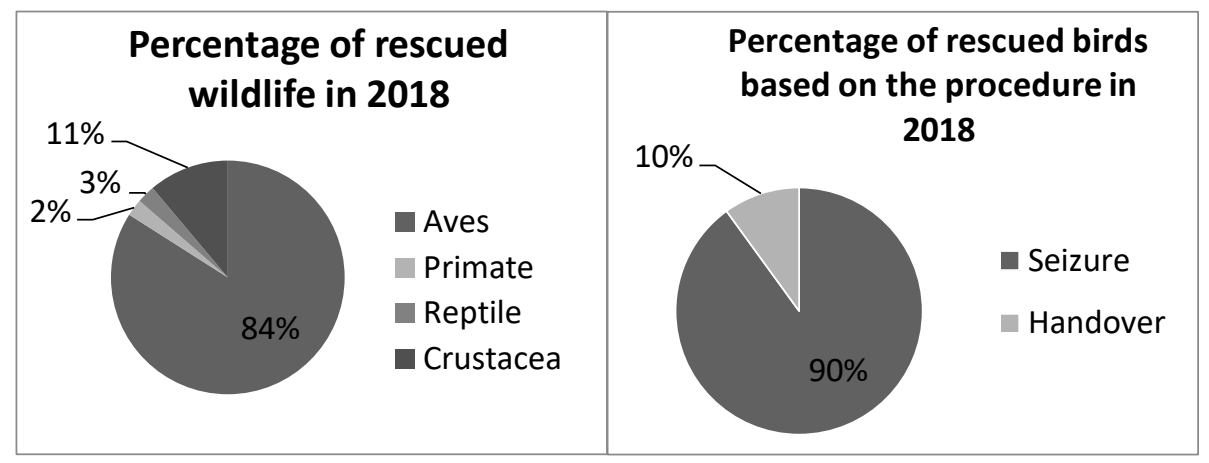

Figure 2. Left: Percentage of rescued wildlife by BKSDA Maluku in 2018; Right: Percentage of rescued wildlife based on procedure in 2018.
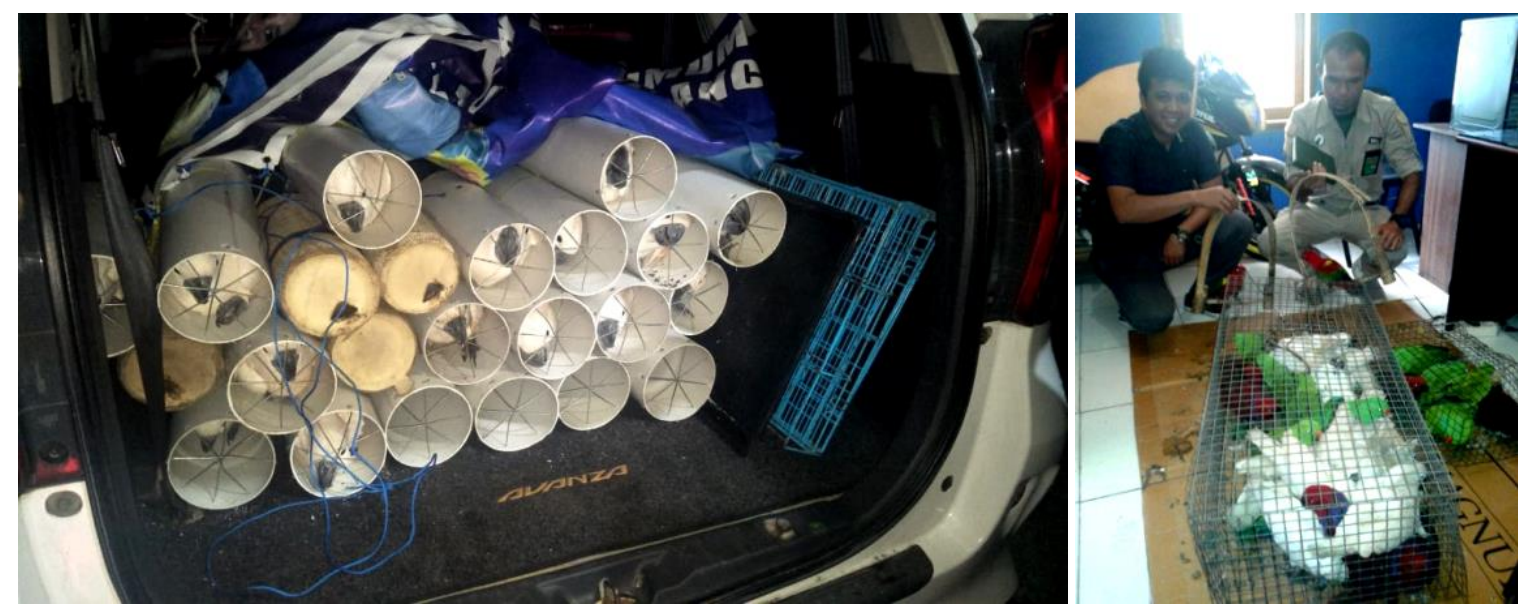

Figure 3. Left: A protected species, Cacatua moluccensis, were seized by BKSDA Maluku officers when transported without any legal permit (Date: 28 December 2018, Location: Hunimua Port, Ambon); Right: Police and BKSDA officers worked together in law enforcement of wildlife crime (Date: 8 May 2018, Location: North Halmahera).

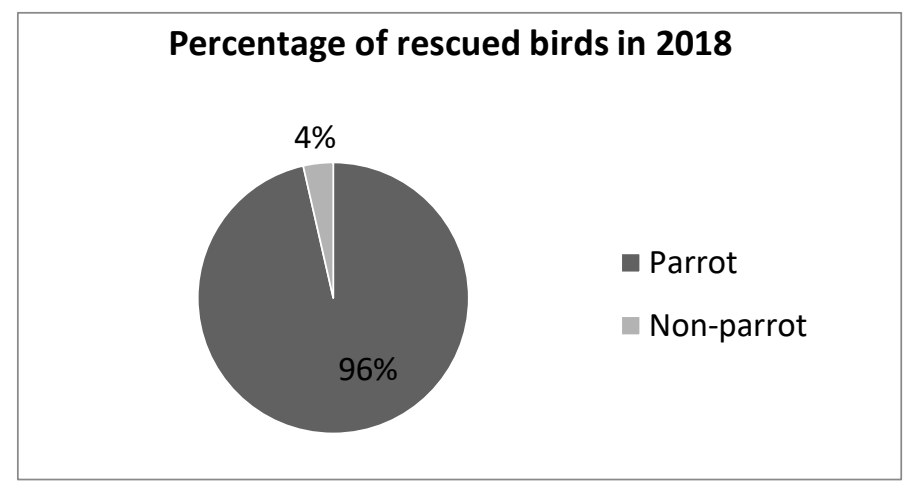

Figure 4. Percentage of rescued bird by BKSDA Maluku in 2018 


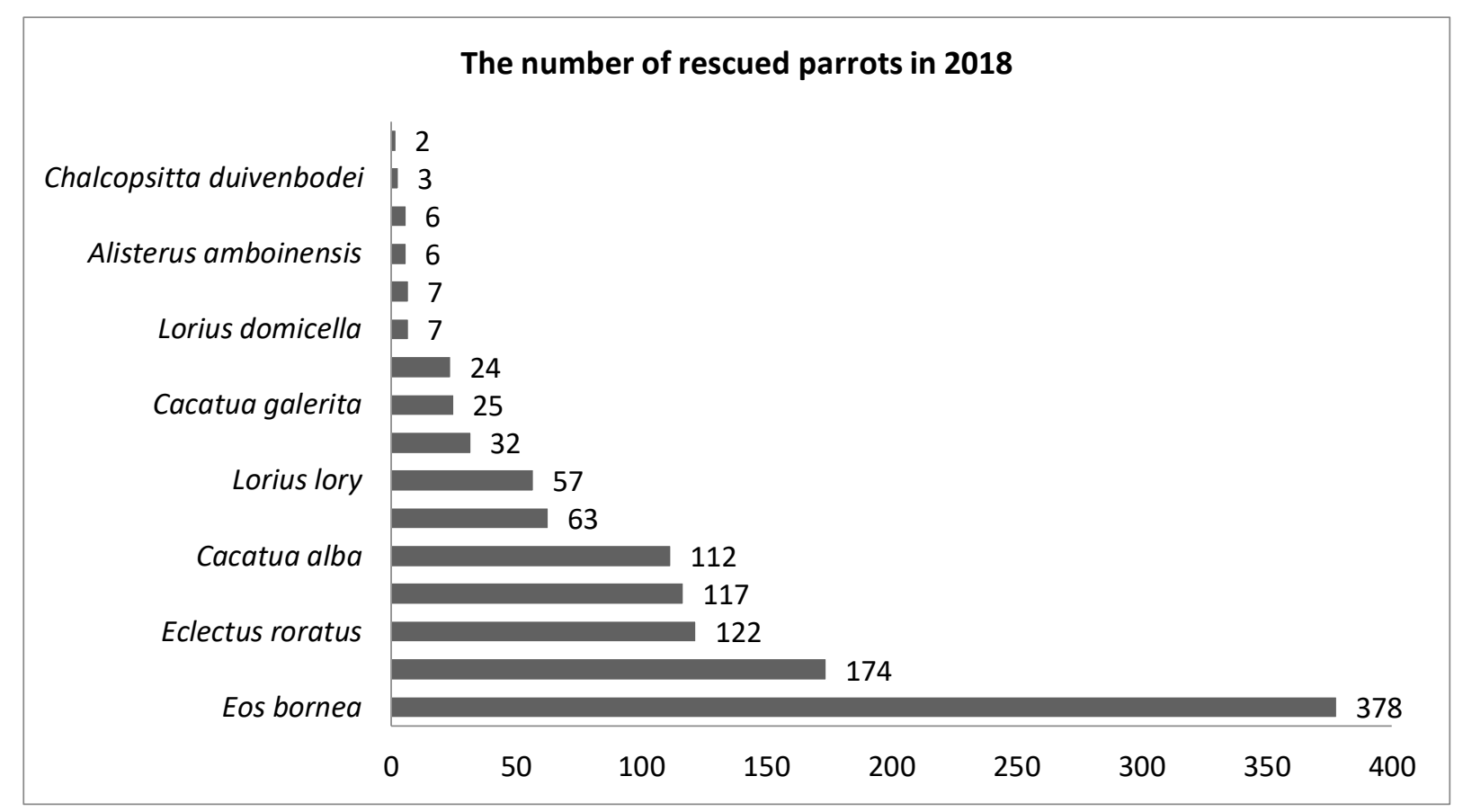

Figure 5. The number of rescued parrots based on species in 2018

In 2018, precisely 1,402 individuals of wildlife were rescued by BKSDA Maluku (see Figure 2). BKSDA Maluku rescued the protected wildlife mostly when they were transported without any legal documents, such as the necessary legal permit (Surat Angkut Tumbuhan dan Satwa Dalam Negeri or SATSDN) (Figure 3). In 2018, approximately 1,060 birds or $90 \%$ of the total rescued birds were seizures from illegal trade and about 10\% (117 individuals) of the total rescued birds were handed over voluntarily by locals (Figure 2).

A total of 1,135 individuals or $96 \%$ of seized birds from illegal trade consisted of parrots (known as Psittacines, in the order of Psittaformes) and merely $4 \%$ (42 individuals) of them were non-parrot species (all kinds of birds, excluding parrots) (Figure 4). This shows that parrots are commonly preferred birds in trade compared to any other birds in the Maluku Islands. In line with this finding, a study on global wildlife trade also showed that parrots are the most preferable species traded illegally (Gilardi, 2006). Furthermore, the study also found that the highest number of illegal parrots traded was Eos bornea, with a total number of 378 individuals annually, followed by Trichoglossus haemadatus, Ecletus roratus, Lorius garrulus, and Cacatua alba. Meanwhile, the least number of parrots were Chalcopsitta duivenbodei and Pseudos fuscata (Figure 5) with a total number of 3 and 2 individuals, respectively. The highest number of Eos bornea rescued by WRU indicates that this species is the most preferable species in illegal parrot trade. Based on interviews, price is the most important determinant that drives harvesters to collect a particular parrot. The supply of parrots on the market is driven by its economic value (Alves, Lima, \& Araujo, 2013) and consumer desire (Gilardi, 2006).

\subsection{Contributing Factors to Illegal Parrot Trade in Maluku}

\subsubsection{Potential Sources}

At least, 12 parrot species out of 16 commonly traded in 2018 were Maluku parrots (Table 1). This indicates that the Maluku Islands are a targeted area for wild-caught parrots in illegal commerce. The illegal trade tends to flourish in Maluku Islands because 34 parrot species (Lepage, 2019) out of 82 Indonesian parrots (BirdLife-International, Data Zone: BirdLife Data Zone, 2019) can be found in Maluku Islands. This high resource potential correlates with Maluku being an important 
spot of mega-biodiversity, a part of the Wallacean region (Myers, Mittermeier, Mittermier, da Fonseca, \& Kent, 2000). The area has complex ecosystem types (Monk, de Fretes, \& ReksodiharjoLilley, 1997) and high level of endemic species, especially avifauna (Coates \& Bishop, 1997).

Table 1. Natural distribution and status of rescued parrots in 2018

\begin{tabular}{|c|c|c|c|c|c|}
\hline No & Species & Distribution & $\begin{array}{l}\text { Protection } \\
\text { Status }\end{array}$ & $\begin{array}{l}\text { IUCN } \\
\text { Status }\end{array}$ & $\begin{array}{l}\text { Population } \\
\text { Trend } \\
\text { (IUCN) }\end{array}$ \\
\hline 1. & Eos bornea & $\begin{array}{l}\text { Maluku (Seram, Buru, Banda Islands, and } \\
\text { Kei Islands) }\end{array}$ & Protected & LC & Decreasing \\
\hline 2. & $\begin{array}{l}\text { Trichoglossus } \\
\text { haematodus }\end{array}$ & $\begin{array}{l}\text { Indonesia (Papua excluding the highland, } \\
\text { Misool, Seram, Ambon, Buru, Aru); New } \\
\text { Caledonia; Papua New Guinea; Solomon } \\
\text { Islands; Vanuatu }^{1}\end{array}$ & Protected & LC & Decreasing \\
\hline 3. & Eclectus roratus & $\begin{array}{l}\text { Indonesia (Halmahera, Morotai, Obi, } \\
\text { Bacan, Seram, Ambon, Buru, Kei, Aru, } \\
\text { Yamdena, Sumba, Papua, and West } \\
\text { Papua); Australia; Papua New Guinea; } \\
\text { Solomon Islands }{ }^{1}\end{array}$ & Protected & LC & Decreasing \\
\hline 4. & Lorius garrulus & $\begin{array}{l}\text { Endemic to North Maluku, from Morotai, } \\
\text { Rau, Halmahera, Widi, Ternate, Bacan and } \\
\text { Obi (BirdLife International, 2001) }\end{array}$ & Protected & VU & Decreasing \\
\hline 5. & Cacatua alba & $\begin{array}{l}\text { Endemic to the islands of Halmahera, } \\
\text { Bacan, Ternate, Tidore, Kasiruta and } \\
\text { Mandiole in North Maluku }{ }^{1}\end{array}$ & Protected & EN & Decreasing \\
\hline 6. & Cacatua goffini & $\begin{array}{l}\text { Restricted to the Banda Sea Islands of } \\
\text { Yamdena and Larat (Tanimbar) with an } \\
\text { introduced population on Kai }{ }^{1}\end{array}$ & Protected & NT & Decreasing \\
\hline 7. & $\begin{array}{l}\text { Cacatua } \\
\text { moluccensis }\end{array}$ & $\begin{array}{l}\text { Endemic to Seram, Ambon, Saparua and } \\
\text { Haruku in South Maluku }\end{array}$ & Protected & VU & Decreasing \\
\hline 8. & Cacatua galerita & Australia; Indonesia; Papua New Guinea ${ }^{1}$ & Protected & $\mathrm{LC}$ & Decreasing \\
\hline 9. & Eos squamata & $\begin{array}{l}\text { North Maluku (Halmahera, Morotaai, } \\
\text { Bacan, Obi) and Papua (Misool and } 3\end{array}$ & Protected & LC & Stable \\
\hline 10. & Lorius domicella & $\begin{array}{l}\text { Endemic to the islands of Seram, Ambon, } \\
\text { and perhaps also Haruku and Saparua, } \\
\text { South Maluku }\end{array}$ & Protected & EN & Decreasing \\
\hline 11. & $\begin{array}{l}\text { Geoffroyus } \\
\text { geoffroyi }\end{array}$ & $\begin{array}{l}\text { Indonesia (Maluku, North Maluku, Nusa } \\
\text { Tenggara, Papua, West Papua); Australia; } \\
\text { Papua New Guinea; Timor Leste }{ }^{1}\end{array}$ & Protected & LC & Decreasing \\
\hline 12. & $\begin{array}{l}\text { Alisterus } \\
\text { amboinensis }\end{array}$ & $\begin{array}{l}\text { Banggai, Halmahera, Taliabu, Buru, Seram, } \\
\text { Ambon, Misool, Waigeo, West Papua }{ }^{3}\end{array}$ & Protected & LC & Decreasing \\
\hline 13. & Lorius lory & $\begin{array}{l}\text { Misool Island, Papua, Papua Barat; Papua } \\
\text { New Guinea }{ }^{1}\end{array}$ & Protected & LC & Decreasing \\
\hline 14. & $\begin{array}{l}\text { Charmosyna } \\
\text { rubronotata }\end{array}$ & $\begin{array}{l}\text { Indonesia (northern Papua and West } \\
\text { Papua); Papua New Guinea }{ }^{3}\end{array}$ & Protected & LC & Stable \\
\hline 15. & $\begin{array}{l}\text { Chalcopsitta } \\
\text { duivenbodei }\end{array}$ & $\begin{array}{l}\text { A patchy distribution along the northern } \\
\text { coastal lowlands of New Guinea, from the } \\
\text { Geelvink Bay in Papua (Indonesia) to the } \\
\text { Astrolobe Bay in Papua New Guinea }{ }^{1}\end{array}$ & Protected & LC & Decreasing \\
\hline 16. & Pseudeos fuscata & $\begin{array}{l}\text { Papua and West Papua; Papua New } \\
\text { Guinea }^{3}\end{array}$ & Protected & LC & Stable \\
\hline
\end{tabular}

${ }^{1}$ BirdLife International, 2018. The IUCN Red List of Threatened Species, 2108; ${ }^{2}$ BirdLife International 2017. The IUCN Red List of Threatened Species 2017; ${ }^{3}$ BirdLife International, 2016. The IUCN Red List of Threatened Species, 2016. 


\subsubsection{Economic Value of Parrots}

In 2018, the total economic value from illegal parrot trafficking in Maluku Islands was no less than IDR 1.4 billion (equivalent to US\$ 110 thousand at a rate of US\$ $1=$ IDR 13,000). This estimation was merely based on the multiplication of the number of rescued parrots from illegal trade and the average market price of each species. At a global scale, illegal wildlife trade is worth US\$10 to 20 billion (Wilson-Wilde, 2010) making it comparable in value to the drug and weapons trades, and human trafficking (Wilson-Wilde, 2010; Harris, et al., 2015). However, the value of illegal wildlife trade is often underestimated due to the lack of accuracy on the real revenue of illegal parrot business.

It is well-known that the price of parrots are affected by its protection status, namely that the rarer the species, the more expensive the price for that given parrot (Shepherd, 2006). Aside from their rarity, the parrot's appearance and abilities also affect which parrots are in high demand. Their appearances with colorful feathers attract many hobbyists to have this species as a pet (Alves, Lima, \& Araujo, 2013). Furthermore, the ability of parrots to mimic human intelligence that is similar to the level of a three-year-old child (Dell'amore, 2018) also increases the demand and price on certain species.

The high price of parrots, however, does not contribute to a profound increase on local welfare. The reason is because the revenue of parrot trade was unequally shared among actors between the harvesters, intermediaries, and consumers (following terminology taken from Pheleps, Biggs, \& Webb, 2016). The wildlife harvesters (or the poachers), are mainly locals, collect the least economic value in comparison with the others (Gilardi, 2006; Alves, Lima, \& Araujo, 2013). For instance, based on an interview with wildlife harvesters, they sold Cacatua moluccensis for IDR 800,000 or roughly US\$ 62 individually. On the other hand, the average price in national markets for the same species was about IDR 4.5 million or US\$346. This price can be more expensive in transnational markets. Similarly, the case of the grey parrot trade estimated that harvesters received roughly $2 \%$ of revenues, whereas international traders benefitted from $80 \%$ (Gilardi, 2006).

\subsubsection{Accessibility}

Due to its geographic location and conditions, Maluku and North Maluku Provinces are accessible and prone to wildlife trafficking. As archipelagic provinces, water transportation becomes a main and important transportation link in the Maluku islands. In total, there are 128 seaports in Maluku, 68 seaports in Maluku Province, and 60 seaports in North Maluku Province, with different levels of seaport hierarchies (Table 2). However, only $24 \%$ of Maluku seaports and $20 \%$ of North Maluku seaports have an official office. Notably, there were 27 cases of confiscated wild-birds in seaports. Furthermore, these provinces are even more vulnerable to transnational trafficking because they are neighbored by other countries, including the Philippines, Australia, and Timor Leste. Bashari \& Nurdin (2009) reported transboundary parrot trafficking occurring between Maluku and Davao City, in the Phillippines.

Table 2. Total Seaports in Maluku and Maluku Province based on port hierarchy in 2017

\begin{tabular}{|c|c|c|}
\hline Seaport & Maluku & North Maluku \\
\hline Main Port & 1 & 1 \\
\hline Collector Port & 7 & 6 \\
\hline Feeder Port & & \\
\hline Regional & 11 & 13 \\
\hline Local & 49 & 40 \\
\hline Total & 68 & 60 \\
\hline
\end{tabular}

Ministry of Transportation (1997). 
Beside the seaport types formally listed, there are also plenty of unregulated ports in these provinces, especially located along coastal villages. These unregulated ports are mainly used by locals for inter village transportation and for delivering people and goods to feeder or collector ports. Harvesters and intermediaries however, often misuse such ports as sites for parrot trafficking. They utilize these ports to ship the parrots directly from forest access points to urban and transboundary cities (Bashari \& Nurdin, 2009).

Another main bird trafficking gate is air transportation. The total airports in these provinces are 14 in Maluku and 12 in North Maluku (Direktorat Jenderal Perhubungan Udara, 2019). Only two out of the 26 airports are classified as international airports, Pattimura International Airport in Maluku Province (Ambon) and Sultan Babullah Airport in North Maluku Province (Ternate), and the remainder are local airports that serve routes between regencies in Maluku and North Maluku. The smaller airports have less sophisticated security systems than the international airports. A number of trafficked parrots (20 individuals of Eos bornea and 16 individuals of Trichoglossus haematodus) were confiscated at Pattimura Airport dated 22 May 2018 however. Due to strict policies of using xrays, airports are the least favorable hubs for transporting birds.

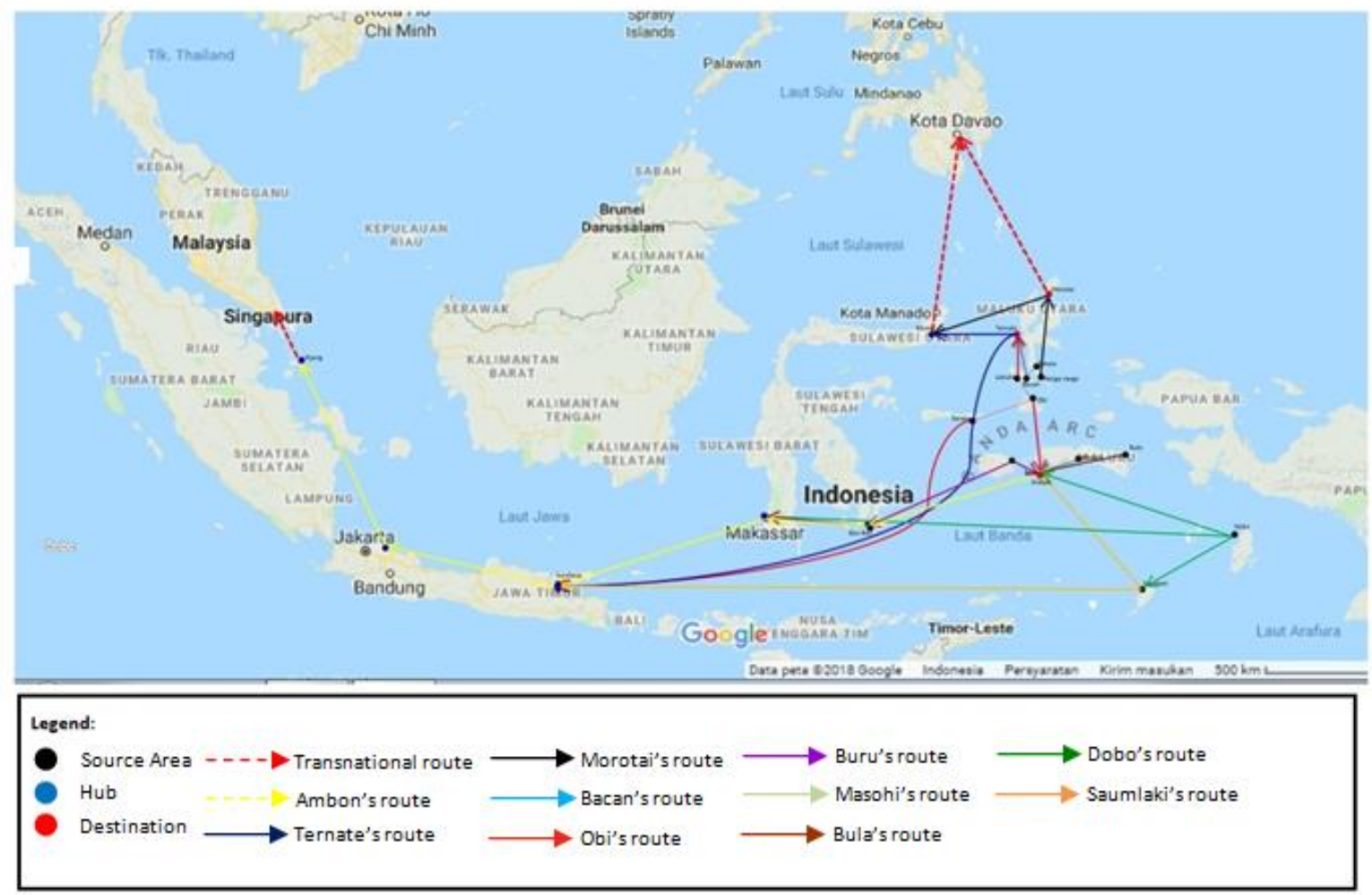

Figure 6. Transport routes of illegal wildlife trade

Although the authorities of seaports and airports have increased their security systems to combat bird trafficking, middlemen have various modes and routes to traffic the birds (Figure 6). The complexity in the illegal parrot trade network is due to the restrictions of accessing resources, getting to transport routes, and apprehending birds among customers at urban and international markets (Pheleps, Biggs, \& Webb, 2016). The parrots are shipped in small numbers without at uncertain times (Bashari \& Nurdin, 2009) and with no fixed routes. The birds are transferred using small cages, pipes, paper boxes, bamboo, and even water bottles (Bashari \& Nurdin, 2009) without any consideration on the welfare of the bird (space, food, water, etc.) (Alves, Lima, \& Araujo, 2013). 
The oversight of these aspects along transportation modes often leads to high mortality rates (Alves, Lima, \& Araujo, 2013) as $90 \%$ of live trafficked wildlife died during transfer (Wilson-Wilde, 2010).

\subsection{Key Actors Involved in Trafficking}

The study identified actors involved in parrot trade, which included subsistence harvesters that often change to oportunistic harvesters to gain additional income. A number of intermediary types include logisticians, third party individuals, and vendors. The end consumers are those who keep parrots as pets. The illegal parrot trade is a complex crime involving many actors that have various roles (Wilson-Wilde, 2010; Alves, Lima, \& Araujo, 2013; Pheleps, Biggs, \& Webb, 2016). Each actor has a different understanding and perspective on their relationship and value towards the parrot. The common similarity across these actors is viewing the parrot as a commodity. Insufficient understanding on the ecological value, population, and endemism of parrots frequently leads to increased trade.

Wildlife harvesters of the parrot trade mostly are subsistence harvesters that collect wild parrots and keep them as pets without any commercial purposes. The harvesters admitted using nets to trap the birds in their sleeping trees or apply gum from Sukun/Breadfruit Tree (Artocarpus altilis). This is similar to Bashari \& Nurdin's (2009) research that stated that harvesters usually use a simple method to capture parrots such as nets, torches, or gum from certain trees. In the Malukus, subsistence harvesters play a role as consumers at the same time. On the other hand, subsistence harvesters often give the parrots to their relatives who live in big cities, such as Ambon, Ternate, and any cities outside Maluku as a gift. However, they also easily can collect and sell parrots if there is the demand. This means there is a unique trend among the harvesters that act across a fluid line between subsistence and oportunistic harvesters.

Most of the havesters, especially oportunistic ones, assume that the parrots are abundant in their backyards. As a result, they capture parrots without much consideration on the declaining populations. They trade parrots to fulfill seasonal events (Gilardi, 2006) such as additional income during the Eid and Christmas holidays (Bashari \& Nurdin, 2009) and to pay school tuition fees for their households. The harvesters, mostly living nearby forests, have a limited understanding about the broader benefits of parrots beyond the ability to translate their capture into cash. In some areas, for instance in Halmahera and Tanimbar, parrots are often considered as pest for agriculture. This notion is unfounded however, given that almost all parrot species are threatened and declining in number (BirdLife-International, 2008; Bashari \& Nurdin, 2009).

Furthermore, all profiles of harvesters, including the subsistence and opportunistic, are abusing or breaking the law. This is because they are breaking a fundamental regulatory mandate in the wildlife protection law. The law itself states that there is a total ban on the collection of any species of parrots in the Maluku Islands (there is no quota for parrots since 2018). Simply put, this means that all wild-caught parrots in bird markets are illegal. Furthermore, harvesters are most-likely breaking the law through their collection activities within park boundaries. For example, this study found that there were cases of poachers colesely engaged in collection of wild parrots in Manusela National Park and Gunung Sibela Reserve.

Harvester prespectives about the abundance of parrots in the wild is commonly exploited by middlemen to keep prices for parrots inexpensive. In addition, giving a down payment to a harvester is also a common practice to gain the lowest price. On the other hand, the middleman has the knowledge about the populations and protection status of wild parrots, and use it to increase the parrot prices among consumers (Shepherd, 2006). In this way they depress the price of purchasing wild-catch parrots from the harvester, while multiplying it for the end user (Alves, Lima, \& Araujo, 2013).

The logisticians are persons that have direct contact with the harvesters in ordering and handling the illegal parrots to another logistician or vendor. Generally, this involves more than one 
logistician in order to transport the wild parrots from the source to the vendors or consumers. The logisticians adapt to increasing law enforcement by using multiple routes, hubs, packaging, and transporting a small number of parrots at random times. Transporting the parrots are assosiated with third parties, such as a crew of ships, and some of them even do not understand their role in the illegal trade. Currently, illegal parrot trade is entering a new phase with the growing role of social media, such as through trade groups on facebook (Budiani \& Raharningrum 2018).

Furthermore, consumers are willing to pay wild-caught parrots at a high price because most of them value the parrots based on their rarity. In addition, having parrots as pets is also a symbol of wealth and balance of life in many cultures (Jepson \& Ladle, 2005; Jepson, 2010). Therefore, it was not a surprise that parrot owners are mostly rich and educated (Jepson \& Ladle, 2005). Compared to other pets, birds are the most preferred household pet in Indonesia (Jepson \& Ladle, 2005; Jepson, 2010). About $21.8 \%$ of Indonesian households in five mega cities (Jakarta, Bandung, Semarang, Surabaya, and Medan) keep birds as pets (Jepson \& Ladle, 2005). In addition, of these, approximately $42.3 \%$ of bird-keeping households own wild-caught parrots (Jepson \& Ladle, 2005).

\subsection{Strategies on countering the illegal parrot trade}

Illegal wildlife trade are often a part of large groups of actors that are well organized (WilsonWilde, 2010) and involves transnational network (Wilson-Wilde, 2010). There are two different proposed strategies based on each actor to counter the illegal parrot trade. The first strategy is protecting parrots based on their sources (the upstream strategy) that targets the harvesters. The other strategy is to cut market chains (the downstream strategy), which focuses on the middlemen and consumers. The upstream strategy addresses the parrot habitat, especially in protected areas and surrounding communities. Meanwhile, the downstream strategy highlights law enforcement and focuses on the middlemen, strengthening stakeholders networking and raising awareness to the consumers.

BKSDA Maluku has conducted routine patrols and monitoring in protected areas and targeted source areas, for instance in Mount Sahuwai Wildlife Park, a well-known habitat of the top targeted parrots, such as Eos bornea, Cacatua moluccensis, Lorius domicella, Trichoglossus haematodus and Eclectus roratus. The patrols aim to prevent any illegal parrot harvesting. Meanwhile, a concomitant goal is the monitoring of populations of species in their habitat.

For the harvesters, particularly subsistence ones, a more humane approach should be selected (Alves, Lima, \& Araujo, 2013). Therefore, BKSDA Maluku conducts community empowerment initiatives as a specific way for treating the source of collectionn. This is because harvesters have important knowledge on identifying the parrots, including parrot's nesting and other behaviors. Their knowledge can be constructively used in scientific management strategies, and as part of wildlife studies (Alves, Lima, \& Araujo, 2013) and conservation efforts. To date, BKSDA Maluku has employed some harvesters as parrot keepers in the Wildlife Rehabilitation Center (Pusat Rehabilitasi Satwa or PRS) in Masihulan. Ecotourism is also another option for the upstream strategy to counter illegal parrot trade. For instance, ecotourism applied by BKSDA Maluku shows a beneficial program for the communities in Masihulan and Taman Jaya communities in Seram, Maluku. One success story from Tanzania is relevant in this light, as ecotourism created sustainable jobs that led to new incentives, which over time led to a decline in the number of people involved in wild bird trade (Gilardi, 2006). Wilson-Wilde (2010) shows that that ecotourism can deliver revenue 2-3 times higher than profit from conventional parrot trade.

Without strict law enforcement, illegal trade will continue to be a major threat of bird conservation (Shepherd, 2006; Gilardi, 2006). BKSDA Maluku has a zero tolerance for intermediaries in the parrot trade. BKSDA Maluku has collaborated with the police on arrests of intermediaries during transport raids of protected species without legal permits. Notably, at least nine cases were processed in court in 2018. BKSDA Maluku has also expanded the monitoring areas to seaports and 
airports identified as important hubs in transferring illegal parrots. In addition, BKSDA Maluku organized stakeholder meetings at the provincial level, declaring that a collaborative commitment is required in order to enhance law enforcement. Thereafter, the collaboration program has worked with NGOs and other institutions, and BKSDA Maluku developed a database system for ground monitoring of prior species, main actors of illegal trade, and identification of network configurations. This database, in turn, can help law enforcement officers to provide evidence to legitimize cases.

On the other hand, a blanket ban is a debatable solution (Gilardi, 2006; Jepson, 2010; Nijman, 2010) to stopping illegal parrot trade. However, a zero quota policy for trading wild parrot species and enlarging parrot species protection status, which were established in 2018 by MoEF Regulation No. $106 / 2018$, was a progressive policy since the previous regulation did not mention all Maluku's parrot species.

Education is also an essential aspect of combating illegal trade, especially to broaden knowledge and raise awareness. Nevertheless, achieving desired knowledge and awareness among communities is a long process because they have their own assumptions about the parrot and what it represents, which has manifested over many years. Therefore, BKSDA Maluku has built intense communication with media (newspapers, online news, television, and radio) to widen the scale of their campaigns, especially in urban cities in Maluku and North Maluku Provinces. By using media channels, BKSDA Maluku actively announces to citizen and calls upon everyone to engage with BKSDA Maluku's call center to report any bird trafficking activities. BKSDA Maluku also works together with civil society to campaign for parrots as part of Maluku's pride. The campaign emphasizes the ecological value and environmental benefits of the parrots, their extinction status, populations and law about parrot trade. As a result, some parrot owners in Ambon City have come realize their impacts, handed over their parrots voluntarily to BKSDA Maluku. Moreover, increasing the number of bird-owners joining such voluntary programs also shows that the communication, outreach, and education strategy has proven effective. In 2018, there were five bird owners that offered their birds voluntarily to BKSDA Maluku, and this participation has increased to a total of 29 bird owners during the period of January to September, 2019.

\section{Policy Recommendations}

Our study encourages further research to focus on the top three species traded illegally, Eos bornea, Trichoglossus haematodus, and Ecletus roratus. Despite these three species categorized as least concerned (LC) by the IUCN red list, the overharvesting identified by our research and others indicates significant effects to the decreasing populations in their natural habitats. Furthermore, a decision of the Red List category is often based on insufficient biological information (Amori \& Gippoliti, 2001) and it is therefore important to conduct field monitoring for greater accuracy on population trends among these species.

Captive-bred parrots, especially on the top 5 of rescued parrots, should be prioritized. Captive breeding is another solution in order to subtitute the wild-caught parrots as pets (Gilardi, 2006), though some previous researchs mention it is not effective way (Shepherd, 2006; Alves, Lima, \& Araujo, 2013). A well known conservation story inn Indonesia is the case of the Bali Starling, which were bred during 2007-2009 with large participation of local bird-breeders and which were successfully released into the Bali Barat National Park (Jepson, 2010). This case demonstrated a clear victory in bird species conservation. Unfortunetaly, there is no private sector support yet for a similar initiative in the Maluku Islands, even though BKSDA Maluku has already experimented with promoting captive-bred parrots. This is because breeding valuable species requires a huge investment.

Further study should focus on improving strategies identified herein and seeking out more effective methods for realizing them. It is understood that some strategies are more effective, particularly law enforcement (Sahide et al., 2018) and awareness campaigns (Lee et al., 2005). The 
trade in Seram for example, declined drastically when a middleman with a large-scale operation (covering the Seram area) was arrested (in February 2019). Although applying such a strategy is effective on tackling illegal parrot trades, in 2019 BKSDA Maluku has already confiscated 588 parrots (between January to September alone), and the current patterns of trade remains likely to continue, particularly during the escalated number of collections that occur in the lead up to religious holidays.

Campaigns to combat illegal parrot trade cannot stop with the harvesters and intermediaries alone. Campaign should also extend to the end consumers in big cities (like in Jakarta, Surabaya, Solo). Educating parrot owners by engaging them about ethical choices and informing them about the destructive impacts of parrot trade, involving cruelty in capture, high mortality during transport, and the risks of animal-human disease transmission are important messages that help to discourage buyers to keep parrots (Jepson \& Ladle, 2005; Wilson-Wilde, 2010; Renctas, 2001 in Alves, Lima, \& Araujo, 2013).

\section{Acknowledgments}

I would like to thank the Wildlife Rescue Unit (WRU) of BKSDA Maluku in collecting and sharing the data on journal publication purposes.

\section{Conflicts of interest}

The authors declare no conflict of interest.

\section{References}

Alves, R. R., Lima, J. R., \& Araujo, H. F. (2013). The live bird trade in Brazil and its conservation: an overview. Bird Conservation International (23), 5365.doi: https://doi.org/10.1017/S095927091200010X.

Amori, G., \& Gippoliti, S. (2001). Identifying priority ecoregions for rodent conservation at the genus level. Oryx , 35, 158-165 doi: https://doi.org/10.1046/j.1365-3008.2001.00164.x

Bashari, H., \& Nurdin, K. (2009). Burung Paruh Bengkok Status Perburuan dan Perdagangannya di Maluku Utara 2008-2009. Bogor: Burung Indonesia.

BirdLife-International. (2019). Data Zone: BirdLife Data Zone. Retrieved July 11, 2019, from BirdLife Data

Zone: http://datazone.birdlife.org/species/results?thrlev1=\&thrlev2=\&kw=\&fam=67\&gen=0\&spc=\& $\mathrm{cmn}=\&$ reg $=2 \& \mathrm{cty}=100 \&$ incvag $=Y$

BirdLife-International. (2008). State of the world's birds: indicators for our changing world. Cambridge, UK: BirdLife International.

Bravo, A., \& Porzecanski, A. L. (2014). Overexploitation of Parrots in Neotropics. In Lesson in Conservation (pp. 51-56).

Budiani, I., \& Raharningrum, F. (2018). Illegal online trade in Indonesian parrots. Geneva, Switzerland.

Coates, B., \& Bishop, K. (1997). Birds of Wallacea. Queensland, Australia: Dover Publications.

Cottee-Jones, H., \& Mittermeier, J. (2015). An overlooked parrot trade hotspots: North Moluccas, Indonesia. Psittascene, 18-21.

Cottee-Jones, H., Mittermeier, J., Purba, E., Ashuri, N., \& Hesdianti, E. (2014). An assesment of the parrot trade on Obi Island (North Moluccas) reveals heavy exploitation of the vulnerable Chattering Lory (Lorius garrulus). Kukila , 1-9.

Dell'amore, C. (2018, June). The humans of the bird world. National Geographic , pp. 92-103.

Direktorat-Jenderal-Perhubungan-Udara. (2019). Bandar Udara. Retrieved July 15, 2019, from Direktorat Jenderal Perhubungan Udara: http://hubud.dephub.go.id/?id/bandara

Gilardi, J. D. (2006). Captured for conservation: will cages save wild birds? A response to Cooney and Jepson. Oryx , 40, 24-26. doi: https://doi.org/10.1017/\$0030605306000160 
Harris, J. B., Green, J. M., Prawiradilaga, D. M., Giam, X., Giyanto, Hikmatullah, D., et al. (2015). Using market data and expert opinion to identify overexploited species in the wild bird trade. Biological Conservation , 187, 51-60. doi: https://doi.org/10.1016/j.biocon.2015.04.009

Hart, J., Hart, L., Salumu, L., Bernard, A., Abani, R., \& Martin, R. (2016). Increasing exploitation of grey parrots in eastern DRC drives population declines. Oryx , 50 (16). doi: https://doi.org/10.1017/\$0030605315001234

Jepson, P. (2010). Towards an Inndonesian Bird Conservation Ethos: Reflections from a Study of Birdkeeping in the Cities of Java and Bali. In S. Tideman, \& A. Golser (Eds.), Ethno-ornitology: Birds, indigenous peoples, culture and society. (pp. 314-330). Earthscan.

Jepson, P., \& Ladle, R. J. (2005). Bird-keeping in Indonesia: conservation impacts and the potential for substitution-based conservation responses. Oryx , 39 (4), 1-6. doi: https://doi.org/10.1017/S0030605305001110

Lee, R. J., Gorog, A. J., Dwiyahreni, A., Siwu, S., Riley, J., Alexander, H., Paoli G.D., \& Ramono, W. (2005). Wildlife trade and implications for law enforcement in Indonesia: a case study from North Sulawesi. Biological Conservation, 123(4), 477-488. doi: https://doi.org/10.1016/j.biocon.2005.01.009

Lepage, D. (2019, June 16). Avi Base-Bird Checklist of The World Maluku Islands. Retrieved July 10, 2019, from Avi Base-The World Bird Database: https://avibase.bsceoc.org/checklist.jsp?region=IDma

Low, R. (1997, May/Juni). The endangered parrots in Indonesia. afa WATCHBIRD , pp. 55-62.

Martin, R. (2018). The wild bird trade and African parrots: past, present and future challenges. Ostrich , 89(2), 139-143. doi: https://doi.org/10.2989/00306525.2017.1397787

May, C. (2017). Transnational Crime and the Developing World. Global Financial Integrity.

Milner-Gulland, E. (2018). Documenting and tackling illegal wildlife trade: change and continuity over 40 years. Oryx , 52(4), 597-598. doi: https://doi.org/10.1017/\$0030605318001047

Ministry-of-Transportation. (1997). Rencana Induk Pelabuhan Nasional (National Port Master Plan). Ministry of Transportation.

Monk, K., de Fretes, Y., \& Reksodiharjo-Lilley, G. (1997). The Ecology of Nusa Tenggara and Maluku. Singapore: Periplus Editions.

Myers, N., Mittermeier, R., Mittermier, C., da Fonseca, G., \& Kent, J. (2000). Biodiversity hotspots for conservation priorities. Nature , 403, 853-858. doi: https://doi.org/10.1038/35002501.

Nijman, V. (2010). An overview of international wildlife trade from Southeast Asia. Biodivers. Conserv. (19), 1101-1114.

Pheleps, J., Biggs, D., \& Webb, E. L. (2016). Tools and terms for understanding illegal wildlife trade. The Ecological Society of America , 14 (9), 476-489. doi: https://doi.org/10.1002/fee.1325.

Pires, S. (2012). The illegal parrot trade: a litterature review. Global Crime , 1-15. doi: https://doi.org/10.1080/17440572.2012.700180

Sahide, M. A. K., Fisher, M. R., Maryudi, A., Dhiaulhaq, A., Wulandari, C., Kim, Y. S., \& Giessen, L. (2018). Deadlock opportunism in contesting conservation areas in Indonesia. Land use policy, 77, 412-424.doi: https://doi.org/10.1016/j.landusepol.2018.05.020

Shepherd, C. R. (2006). The bird trade in Medan, North Sumatra: An Overview. BirdingASIA (5), 1624.

Tamalene, M., Hasan, S., \& Kartika. (2019). Local knowledge and community behaviour in the exploitation of parrot in surrounding area of Aketajawe Lolobata National Park. Biosfer: Jurnal Pendidikan Biologi , 12, 24-33. doi: https://doi.org/10.21009/biosferjpb.v12n1.24-33

Weston, M., \& Memon, M. (2009). The illegal parrot trade in Latin America and its concequences to parrot nutrition, health, and conservation. Bird Population , 9, 76-83.

Wilson-Wilde, L. (2010). Wildlife crime: a global problem. Forensic Sci. Med. Pathol. (6), 221-222. doi: https://doi.org/10.1007/s12024-010-9167-8 